\title{
ANALISIS GAYA BELAJAR DAN PERILAKU BISNIS PENGUSAHA KECIL BIDANG AGRIBISNIS DI KOTA KENDARI
}

\author{
(LEARNING STYLES AND BUSINESS BEHAVIOR OF SMALL \\ AGRIBUSINESS ENTREPRENEUR IN KENDARI)
}

\author{
Usman Rianse, Weka Gusmiarty Abdullah, dan La Ode Alwi \\ Jurusan Agribisnis Fakultas Pertanian Universitas Haluoleo \\ Sulawesi Tenggara, Indonesia \\ agribisnishaluoleo@yahoo.co.id
}

\begin{abstract}
The absence of information regarding business learning styles and behavior of small entrepreneurs in the agribusiness field in Kendari city can lead to less precise determination of creative economic policy in the Kendari city. This study aims to: determine the type of business learning style and behavior of small entrepreneurs in the agribusiness field in Kendari city. Analysis of learning styles performed by calculating the level of rank (from left to right) was made by the respondents to the questionnaire that has been provided based on the level of compatibility with the learning behavior of respondents. Analysis of the entrepreneurs's behavior carried out by observing the dominance of respondents's answering on the questionnaire (19 questions) that have been provided. The results showed that learning style of the small entrepreneurs in the agribusiness field in Kendari city spread into 4 (four) types of learning styles, in the following order: $38.89 \%$ assimilator type, $27.78 \%$ converger type, $16.67 \%$ respectively for acomodator and diverger type. Business behavior of small entrepreneurs in the agribusiness field in Kendari city clustered on the behavior of III (100\%), nomely the ethical business behavior (clean businness). Among that entrepreneurs who behave $100 \%$ clean business behavior, there were $38.89 \%$ of entrepreneurs who conduct very strong (high) clean business and $61.11 \%$ who conduct rather low clean business.
\end{abstract}

Keywords: Learning Styles, Business Behavior, Small Entrepreneur, Agribusiness

\section{PENDAHULUAN}

Wirausaha adalah perspektif baru dalam menetapkan pilihan untuk meniti karier kehidupan. Semangat wirausaha perlu semakin ditingkatkan agar penduduk tidak lagi membatasi lapangan kehidupannya sendiri dengan hanya terpaku menjadi pencari lapangan pekerjaan (Welirang, 2007). 
Kewirausahaan di Kota Kendari Sulawesi Tenggara (Sultra) saat ini menunjukkan kecenderungan pertumbuhan yang menggembirakan. Ini terlihat dengan adanya peningkatan usaha kecil menengah (UKM) yang ditandai dengan peningkatan jumlah unit usaha sebanyak 751 unit selama tahun 2008 (Alam, 2009; dalam Jafam-ICT.com, 2009) mengatakan bahwa tahun 2007, jumlah usaha perdagangan di Kota Kendari sebanyak 2.990 unit dan di tahun 2008 meningkat menjadi 3.741 unit (usaha perdagangan naik 751 unit atau naik sekitar 25\%). Dari 3.741 unit usaha perdagangan saat ini, terdiri dari usaha skala kecil sebanyak 2.440 unit, skala menengah 976 unit, dan skala besar 325 unit. Usaha skala kecil ini menyerap tenaga kerja sekitar 9.326 orang, skala menengah 4.879 orang, dan skala besar 2.846 orang.. Dari kenaikan 751 unit tersebut terdiri dari usaha kecil 475 unit, menengah 191 unit, dan besar 85 unit. Rincian kenaikan usaha skala kecil di Kota Kendari sebagaimana pada Tabel 1.

Tabel 1. Kenaikan Usaha Kecil Menengah di Kota Kendari Tahun 2007 2008

\begin{tabular}{clc}
\hline No & \multicolumn{1}{c}{ Jenis Usaha } & Jumlah UKM \\
\hline 1 & Industri Makanan dan Minuman & 108 \\
2 & Perikanan, Peternakan dan Pendukung & 11 \\
3 & Industri Meubel Kayu & 49 \\
4 & Usaha Kertas dan Percetakan & 45 \\
5 & Usaha Foto Studio & 10 \\
6 & Industri Bahan Bangunan & 21 \\
7 & Jasa Reparasi dan Perbengkelan & 125 \\
8 & Industri Sandang & 77 \\
9 & Industri Kerajinan Emas, Perak dan Ukiran Gembol & 29 \\
\hline \multicolumn{2}{c}{ Total } & 475 \\
\hline
\end{tabular}

Sumber: Data Directory Pengusaha Kecil dam Menengah Kota Kendari 2007

Peningkatan usaha kecil menengah tersebut perlu dipertahankan bahkan terus ditingkatkan. Demikian juga khususnya pada usaha kecil menengah bidang agribisnis. Berdasarkan Tabel 1 bahwa kenaikan industri makanan dan minuman meningkat hingga 108 unit dalam 1 tahun, sedangkan usaha bidang perikanan, peternakan, dna pendukung meningkat sebanyak 11 unit. Kedua jenis usaha tersebut termasuk kategori bidang usaha agribisnis. Ini berarti bahwa agribisnis sebenarnya merupakan salah satu harapan sumber penghasilan di masa depan.

Para pengusaha kecil bidang agribisnis dituntut selalu belajar dan berperilaku baik (beretika) untuk mempertahankan eksistensinya dalam dunia kewirausahaan, maupun dalam menyebarkan wabah wirausaha. Belajar yang dimaksud dalam hal ini adalah upaya memahami dan mengimplementasikan strategi untuk menciptakan kelanggengan usaha, pengembangan usaha, dan 
strategi membantu menciptakan bibit-bibit pengusaha-pengusaha baru di lingkungan sekitarnya. Sementara perilaku bisnis yang dimaksud adalah tindakan pengusaha menjalankan bisnisnya dalam rangka mencapai keuntungan bisnis yang ditargetkan.

Dengan demikian sangat penting untuk dikaji bagaimana gaya belajar dan perilaku bisnis para pengusaha kecil bidang agribisnis di Kota Kendari. Hal ini dapat menjadi informasi yang sangat penting untuk mengetahui tipe gaya belajar apa yang lebih dominan dibutuhkan untuk pengembangan usaha kecil bidang agribisnis di kota kendari, serta bagaimana perilaku bisnisnya. Hal ini juga penting sebagai bahan pertimbangan bagi penentuan kebijakan ekonomi kreatif yang dapat mudah diadopsi oleh para pengusaha kecil agribisnis di kota Kendari.

\section{METODE PENELITIAN}

Penelitian ini merupakan jenis penelitian deskriptif analitis. Pada pelaksanaannya, penelitian ini menggunakan tehnik survei. Daerah penelitian ditentukan secara purposive di Kota Kendari, Provinsi Sulawesi Tenggara. Penentuan sampel petani dilakukan dengan metode simple random sampling sehingga diperoleh Jumlah sampel sebanyak 36 orang pengusaha kecil yang bergerak di bidang agribisnis.

\section{Analisis Gaya Belajar}

Analisis gaya belajar dilakukan dengan menghitung peringkat rangking (dari kiri ke kanan) yang dilakukan oleh para responden terhadap kuisioner yang telah disediakan (lampiran 1) berdasarkan tingkat kecocokan dengan perilaku belajar responden (Mitimahasiswa, 2009).

Makna rangking :

$4=$ paling cocok dengan sikap belajar responden

$3=$ paling cocok kedua dengan sikap belajar responden

2 = paling cocok ketiga dengan sikap belajar responden

$1=$ paling tidak cocok dengan sikap belajar responden

Penghitungan perangkingan dilakukan di setiap kolom pertanyaan (ada 4 kolom). Makna masing-masing kolom (dari kiri ke kanan), sebagai berikut :

Kolom 1= PN/CE; Pengalaman Nyata atau Concentrate experience

Kolom 2= PC/RO; Pengamatan Cermat atau Reflective Observation

Kolom $3=\mathrm{KA} / \mathrm{AC}$; Konseptualisasi Abstrak atau Abstract Conceptualization

Kolom 4= EA/AE; Ekspansi Aktif atau Active Experimentation

Langkah-langkah analisis gaya belajar, sebagai berikut (Nurjaman, 2009): 
1) Memasukkan total skor pada pada tiap kolom ke dalam kolom-kolom di bawah ini :

\begin{tabular}{|c|c|c|c|}
\hline Kolom 1 & Kolom 2 & Kolom 3 & Kolom 4 \\
$\mathrm{PN} / \mathrm{CE}$ & $\mathrm{PC} / \mathrm{RO}$ & $\mathrm{KA} / \mathrm{AC}$ & $\mathrm{EA} / \mathrm{AE}$ \\
\hline
\end{tabular}

2) Meletakkan titik pada tiap garis sesuai dengan skor PN, PC, KA, EA,

3) Menghubungkan titik-titik tersebut dengan garis lurus, sehingga akan diperoleh bentuk seperti layang-layang. Bentuk dan letak layanglayang akan memperlihatkan suasana belajar responden yang paling disukai dan kurang disukai.

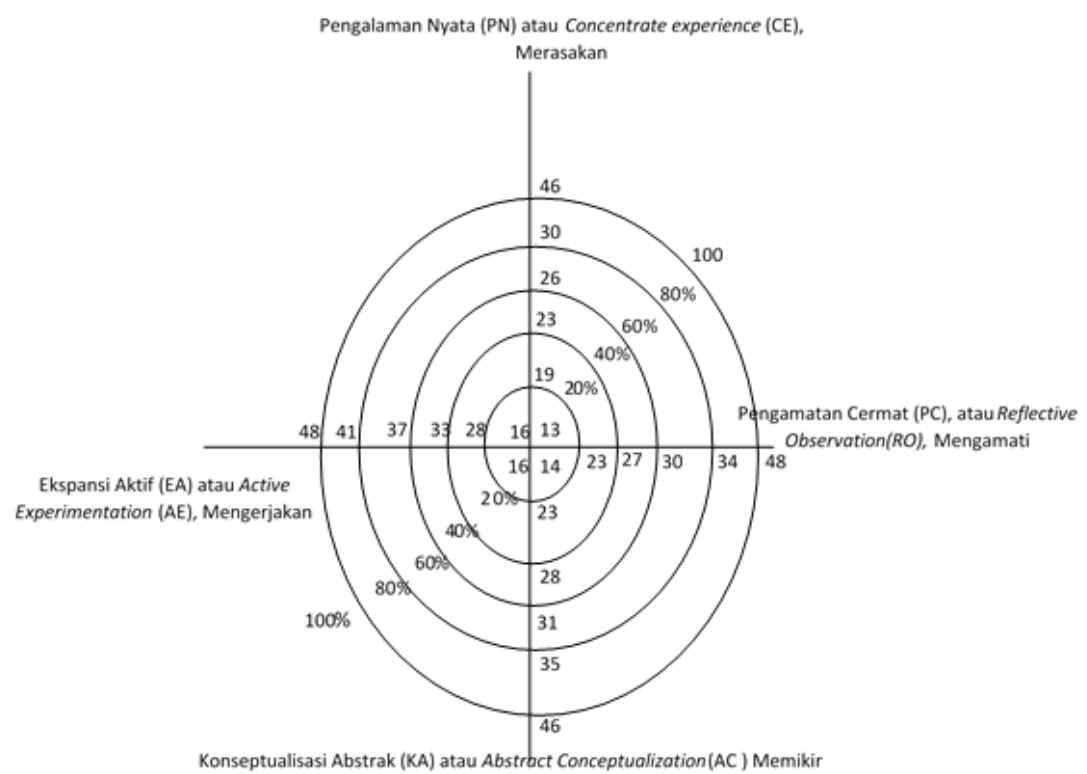

4) Mengambil 4 skor dari 4 siklus belajar (PN, PC, KA, EA) dan melakukan pengurangan seperti di bawah ini:
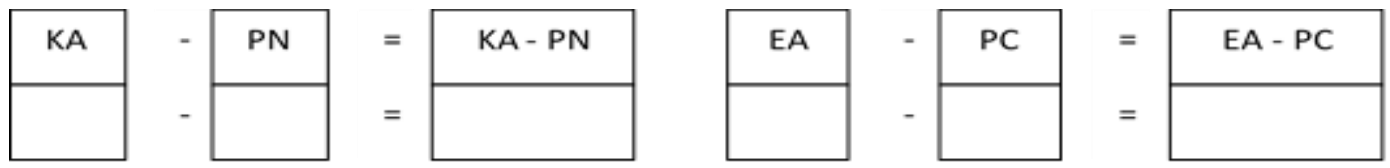

\section{Keterangan :}

a. Skor positif pada KA - PN menjelaskan kalau skor Anda lebih teoritis.

b. Skor negatif pada KA - PN menjelaskan kalau skor Anda lebih praktis.

c. Skor positif pada EA - PC menjelaskan kalau skor Anda lebih aktif.

d. Skor negatif pada EC - PC menjelaskan kalau skor Anda lebih cermat (reflektif).

5) Membuat 2 kombinasi dari 2 skor: KA - PN dan EA - PC,

Usman Rianse, Weka Gusmiarty Abdullah, dan La Ode Alwi. Analisa... | 242 
6) Meletakkan masing-masing skor tersebut pada 2 garis grid di bawah ini dan memplot titik pertemuan, maka akan ditemukan gaya belajar dari 4 gaya belajar.

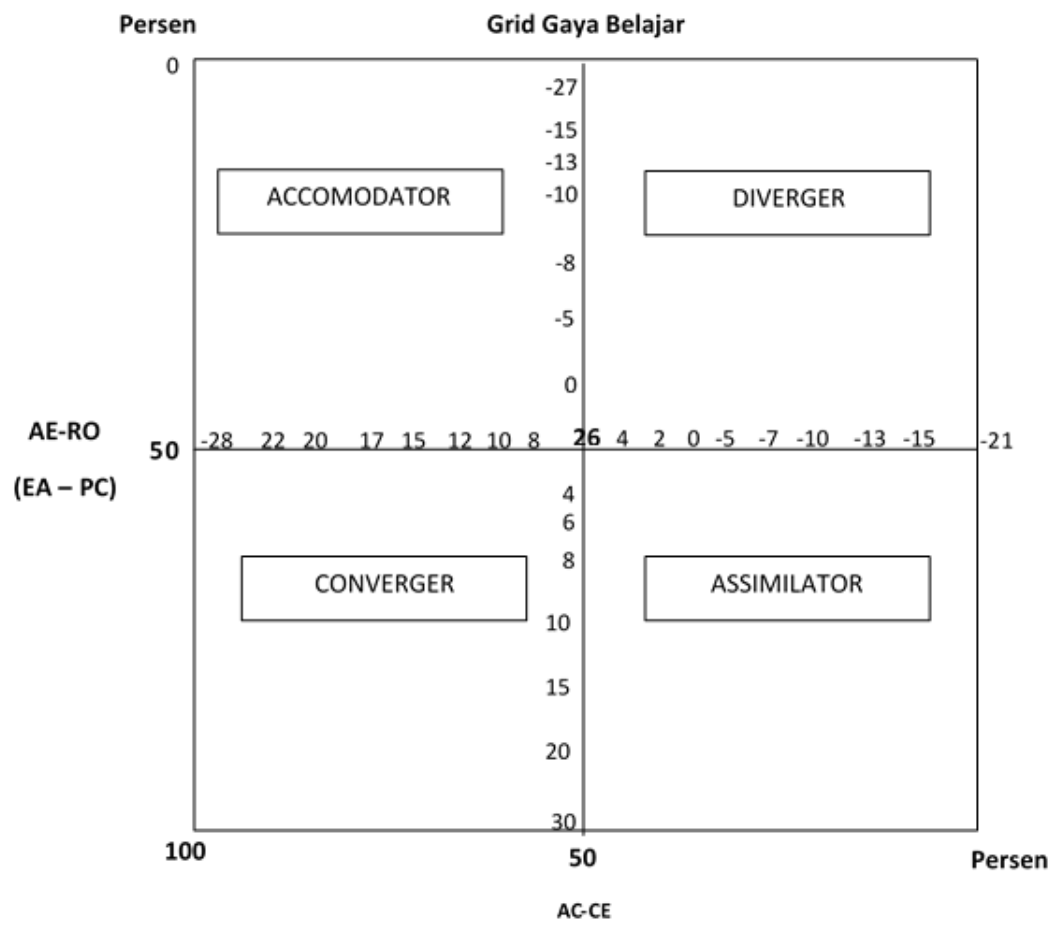

\section{Analisis Perilaku Bisnis}

Analisis perilaku pengusaha dilakukan dengan mengamati dominasi jawaban responden pada kuisioner (19 pertanyaan) yang telah disediakan (lampiran 2). Pengkualitatifan data dilakukan dengan memberi makna angka pada setiap pilihan jawaban; jawaban A bernilai 1, jawaban B bernilai 2, dan jawaban C bernilai 3, dan selanjutnya menentukan perilaku berdasarkan kategori nilai yang ditentukan, sebagai berikut (Setyowati, 2009):

a. Clean business untuk skor jawaban $39-57$.

b. Cukup berpotensi Clean business untuk skor jawaban $20-38$.

c. Capitalis business untuk skor jawaban $0-19$. 


\section{HASIL DAN PEMBAHASAN}

\section{Gaya Belajar Pengusaha Kecil Bidang Agribisnis di Kota Kendari}

Kemampuan belajar adalah keterampilan yang sangat penting bagi seorang pengusaha. Dengan memahami gaya belajar, pengusaha akan menjadi pemecah masalah yang efektif. Hampir setiap masalah yang dihadapi di pekerjaan atau dalam hidup akan menyangkut keterampilan untuk :
a. Identifikasi masalah,
b. Memilih masalah yang akan diselesaikan,
c. Mengenali berbagai cara pemecahan yang berbeda,
d. Mengevaluasi kemungkinan hasil,
e. Melaksanakan pemecahan.

Berdasarkan hasil analisis, diperoleh data gaya belajar pengusaha kecil bidang agribisnis di kota Kendari sebagaimana pada Tabel 2.

Tabel 2. Gaya Belajar Pengusaha Kecil Bidang Agribisnis di Kota Kendari

\begin{tabular}{lcc}
\hline \multirow{2}{*}{ Gaya Belajar } & Jumlah Pengusaha Kecil Bidang Agribisnis (Orang) \\
\cline { 2 - 3 } & Orang & Persen (\%) \\
\hline Konverger & 10 & 27,78 \\
Diverger & 6 & 16,67 \\
Asimilator & 14 & 38,89 \\
Akomodator & 6 & 16,67 \\
\hline Total Responden & 36 & 100 \\
\hline
\end{tabular}

Pada Tabel 2, diketahui bahwa terdapat 10 (27,78\%) pengusaha kecil bidang agribisnis di Kota Kendari dengan gaya belajar sebagai seorang konverger. Tipe ini terletak di antara model pemahaman konseptualisasi abstrak dengan eksperimen aktif. Pengusaha yang berada dalam kelompok ini sangat senang mengaplikasikan ide-idenya secara praktis. Mereka cenderung mampu bereaksi secara cepat, tetapi para pengusaha ini akan lebih suka berhadapan dengan tugas-tugas dan masalah-masalah teknis daripada masalah-masalah sosial dan antar perseorangan.

Bergaya belajar sebagai konverger berarti mempunyai kemampuan memecahkan masalah-masalah dan membuat keputusan-keputusan berdasarkan pada temuan pemecahan-pemecahan untuk pertanyaanpertanyaan atas permasalahan-permasalahan. Mereka sangat senang jika berada dalam situasi yang jelas dan tidak mengambang. Kelebihan kelompok ini adalah; mereka sangat mudah untuk penasaran, senang mengambil keputusan, menguji solusi dengan praktik langsung dan cerdas dalam menentukan sasaran serta menentukan prioritasnya. Kelemahan kelompok ini adalah; tidak sabar, memiliki semangat untuk beraksi, lebih berorientasi 
kepada tugas daripada orang-orangnya dan tidak senang dengan alternatifalternatif.

Cara belajar yang efektif bagi para pengusaha ini adalah jika mereka bisa menggambarkan kesimpulan-kesimpulannya sendiri, jika segala sesuatunya jelas dan memiliki relevansi praktis terhadap permasalahan. Para pengusaha dengan tipe ini akan mudah belajar jika mereka ditunjukkan/didemonstrasikan segala sesuatunya atau mencoba sesuatu dengan bantuan ahlinya dan lebih mudah belajar jika mereka mampu mengembangkan aktivitas dengan hasil yang jelas.

Hal yang menarik bahwa terlihat ada perbedaan antara teori dengan hasil analisis pada penelitian ini, yaitu semua pengusaha kecil bidang agribisnis yang tergolong konverger berkarakteristik teoritis aktif. Hal ini dapat dijelaskan bahwa objek penelitian ini adalah para pengusaha dalam skala kecil sehingga sebagian besar diantara mereka bertindak berdasarkan teori-teori atau pengalaman nyata dan kurang berani risiko. Hal ini akan berbeda pada pengusaha skala sedang hingga besar. Kebanyakan para pengusaha tersebut senang bereksperimen dan berani risiko. Salah satu penyebabnya karena mereka memiliki cukup modal untuk bereksperimen serta pengalaman berwirausaha yang cukup banyak. Para pengusaha kecil bidang agribisnis dengan tipe konverger, meskipun berkarakteristik teoritis, mereka cenderung aktif juga bereksperimen dan mengambil keputusan-keputusan berdasarkan teori-teori yang diperolehnya.

Enam $(6,67 \%)$ pengusaha kecil bidang agribisnis gaya belajarnya bersifat diverger (Tabel 2). Tipe ini terletak di antara model pengalaman nyata dan pengamatan cermat reflektif. Para pengusaha tipe diverger ini sangat tepat dalam melihat situasi konkrit dari berbagai sudut pandang, dan memiliki kemampuan imajinasi dan sensitivitas yang sangat baik. Mereka yang berada dalam kelompok ini cenderung terbuka terhadap pengalaman baru, kemudian mereka akan berfikir dan menganalisa atas pengalaman tersebut. Pada saat bertindak para pengusaha kecil bidang agribisnis ini akan menempatkan pandangan orang lain sebagai pertimbangan.

Kelebihan pengusaha dengan gaya belajar diverger adalah mampu mencari informasi-informasi di balik sebuah berita, mampu mengenali dan membedakan permasalahan-permasalahan yang muncul, serta mampu membedakan hasrat dan keadaan saat ini. Mereka adalah tipe orang yang umumnya mampu menggali opini-opini orang lain. Beberapa kelemahan umum kelompok ini, seperti; cenderung kurang aktif tetapi banyak ide. Pengusaha tipe diverger ini adalah tipe pengharap. Keadaan tersebut membuat mereka tidak sanggup melihat dengan arif dan detail jika permasalahan yang dihadapi terlalu banyak.

Para pengusaha kecil bidang agribisnis dengan gaya belajar diverger akan belajar dengan efektif; jika diberikan waktu yang cukup mengolah 
observasi; jika permasalahan dipresentasikan secara visual; jika berkesempatan mendengar dan mengobservasi; akan lebih baik jika berkesempatan melakukan pengulangan dengan menuliskan laporan atau analisa sesudah mereka menerima/melihat hal baru tersebut. Hal yang paling mencolok adalah mereka akan belajar dengan sangat efektif jika tidak ada tekanan dari pihak luar.

Hal yang menarik bahwa semua pengusaha kecil bidang agribisnis di Kota Kendari yang bertipe diverger berkarakteristik praktis; 3 pengusaha praktis cermat dan 3 pengusaha praktis aktif. Para pengusaha ini berpikir praktis namun cermat dalam melihat berbagai permasalahan dan mencari alternatif pemecahannya. Sebagian pengusaha dalam kategori ini berpikir praktis dan tanggap dalam pelaksanaan pemecahan berbagai permasalahan yang dihadapi.

Jiwa seni yang menonjol dari tipe diverger ini akan sangat baik bagi seorang manajer dalam mengelola manajemennya. Ini karena manajemen sendiri merupakan suatu seni sehingga agar dapat mengelola manajemen bisnis secara baik perlu ditunjang dengan berbagai ide-ide kreatif.

Berdasarkan Tabel 2, diketahui bahwa ternyata terdapat 14 (38,89\%) pengusaha kecil bidang agribisnis yang gaya belajarnya adalah asimilator. Tipe ini terletak di antara model pemahaman pengamatan cermat reflektif dan konseptualisasi abstrak. Pengusaha dalam tipe ini paling tepat dalam memahami sejumlah besar informasi dan mengartikannya ke dalam bentuk yang konkrit dan logik. Para pengusaha tersebut memikirkan segala permasalahan dan tatanan yang terstruktur.

Keunggulan tipe asimilator adalah; cerdas menemukan solusi-solusi alternatif; sangat cerdas memanfaatkan pengalamannya dalam kehidupan sehari-hari; sangat logis dan senang atas ketepatan; cerdas untuk mengorganisasikan dan merencanakan sesuatu. Kelemahan tipe ini adalah sering menempatkan teori lebih dalam daripada kenyataannya; mereka dengan kemampuan berpikirnya cenderung menghindari risiko; mereka secara jelas terlihat tidak terlalu memperhatikan perasaan dirinya dan orang lain; orang ini memiliki perasaan akan kenyataan yang cukup minim.

Para pengusaha kecil bidang agribisnis asimilator akan sangat mudah belajar jika; mereka diberikan struktur yang jelas; jika mereka mampu mengamati segala sesuatu secara logis; jika mereka membekali dirinya dengan berbagai data; dan mereka akan sangat efektif dalam belajar jika segala sesuatunya teratur dan hening untuk berfikir.

Hal yang menarik bahwa ternyata 38,89\% pengusaha kecil bidang agribisnis termasuk kategori asimilator atau sering pula disebut sebagai para pemikir (thinker). Pada kategori ini, terdapat 7 pengusaha berkarakteristik teoritis cermat, dan 7 pengusaha berkarakteristik teoritis aktif. Orang-orang dengan gaya belajar asimilator ini biasanya beraktivitas dalam karir informasi dan ilmu pengetahuan. Ini tidak berarti bahwa para pengusaha dengan tipe ini tidak akan langgeng dan sukses karirnya sebagai pebisnis. Keunggulan- 
keunggulan para pengusaha bertipe asimilator ini sebenarnya sangat potensial bagi pengembangan bisnis. Kecerdasan dalam menemukan solusi-solusi alternatif, dalam memanfaatkan pengalamannya dalam kehidupan sehari-hari, dan kecerdasan dalam mengorganisasikan dan merencanakan sesuatu adalah merupakan langkah-langkah untuk mencapai kesuksesan. Ini harus diimbangi dengan meminimalkan berbagai kelemahan dan menjalin kerjasama dengan pengusaha dengan tipe diverger, akomodator, dan konverger.

Enam pengusaha kecil bidang agribisnis $(16,67 \%)$ di Kota Kendari memiliki gaya belajar akomodator (Tabel 2). Tipe ini terletak di antara model pemahaman eksperimentasi aktif dan pengalaman nyata. Para pengusaha yang akomodator menyukai pelaksanaan suatu rencana dan melibatkan diri dalam pengalaman baru dan menantang. Kecenderungan para pengusaha untuk bertindak kemungkinan lebih banyak berdasarkan perasaan 'yang mendalam' daripada hasil analisis logika. Dalam memecahkan masalah, para pengusaha akomodator mungkin lebih mengandalkan informasi yang didapat dari orang lain daripada analisis teknis Anda sendiri.

Kekuatan kelompok ini adalah; cenderung aktif, penuh harap, penuh intuasi dan berhubungan baik dengan orang lain bahkan mampu memotivasi orang lain. Kelemahannya adalah; seringkali sangat tidak sabaran, cepat menyerah dan jarang menyelesaikan pekerjaannya. Pengusaha dengan tipe akomodator tidak suka dengan teori-teori dan tidak baik dalam mengorganisir dan merencanakan sesuatu.

Belajar yang paling efektif bagi pengusaha kecil bidang agribisnis akomodator ini adalah ketika mereka berada pada lingkungan yang menawarkan tantangan-tantangan yang konstan; jika merasa terdesak; atau bila bekerja dengan intensif dalam kelompok yang cocok; lebih baik jika mereka memiliki latar belakang pendidikan dan pelatihan yang bervariasi.

Akomodator sebenarnya adalah ujung tombak dalam pemasaran. Merekalah yang berinteraksi langsung dengan konsumen. Hal yang menarik bahwa dari 36 responden pengusaha kecil bidang agribisnis, hanya 6 orang $(16,67 \%)$ yang gaya belajarnya akomodator. Dari 6 pengusaha akomodator, 3 pengusaha berkarakteristik praktis aktif, dan 2 pengusaha berkarakteristik teoritis aktif. Ini menunjukkaan bahwa memang pengusaha dengan gaya belajar akomodator menyukai aktivitas pemasaran meskipun sebagian diantara mereka ada yang hanya mendasarkan kegiatannya pada teori-teori pemasaran namun sebagian lagi gemar bereksperimen dalam kegiatan pemasarannya.

\section{Perilaku Bisnis Pengusaha Kecil Bidang Agribisnis di Kota Kendari}

Perilaku bisnis ini terdiri atas 3 macam; pengusaha yang berperilaku clean bisnis (perilaku 1), perilaku yang sangat berpotensi untuk berperilaku clean bisnis (perilaku 2), dan perilaku yang tidak beretika atau perilaku yang seringkali menghalalkan berbagai macam cara demi meraih keuntungan 
maksimal (perilaku 3). Alternatif pilihan jawaban dari setiap responden selanjutnya diskoring. Perilaku Bisnis pengusaha kecil bidang agribisnis di Kota Kendari sebagaimana Tabel 3.

Tabel 3. Perilaku Bisnis Pengusaha Kecil Bidang Agribisnis di Kota Kendari.

\begin{tabular}{lrc}
\hline \multirow{2}{*}{ Perilaku } & \multicolumn{2}{c}{ Jumlah responden } \\
\cline { 2 - 3 } & orang & Persen $(\%)$ \\
\hline Perilaku I & 0 & 0 \\
Perilaku II & 0 & 0 \\
Perilaku III & 36 & 100,00 \\
Tinggi & 14 & 38,89 \\
Rendah & 22 & 61,11 \\
\hline
\end{tabular}

Tabel 3 menunjukkan bahwa tidak seorang pun diantara responden pengusaha kecil bidang agribisnis di Kota Kendari yang tidak berpotensi sebagai wirausahawan. Seratus persen responden berjiwa wirausaha kuat yang berperilaku sebagai pengusaha clean bisnis, dengan rincian: 22 orang $(61,11 \%)$ berperilaku clean bisnis sejati, dan 14 orang $(38,89 \%)$ berperilaku clean bisnis cukup kuat.

Dari analisis tersebut mengindikasikan bahwa persaingan usaha yang berkembang di Kota Kendari umumnya dan usaha kecil bidang agribisnis Kota Kendari khususnya merupakan persaingan sehat. Suasana clean business ini sangat baik bagi pengembangan bisnis agribisnis di masa mendatang. Dominasi perilaku clean business pada para pengusaha kecil bidang agribisnis di Kota Kendari ini akan menciptakan suasana bisnis yang harmonis dan akan sangat bermanfaat bagi masyarakat non pebisnis. Ini disebabkan oleh berbagai nilai-nilai positif yang terkandung di dalam diri para pengusaha yang berperilaku clean business, seperti; sikap pengandalian diri yang baik, pengembangan tanggung jawab sosial, memiliki jati diri dan tidak mudah terombang-ambing oleh pesatnya perkembangan informasi dan teknologi, melakukan persaingan sehat, menerapkan konsep pembangunan berkelanjutan, menghindari sifat 5K (katabelece, kongkalingkong, koneksi, kolusi, komisi), menyatakan yang benar itu benar, menumbuhkan sikap saling percaya diantara golongan pengusaha, konsekuen dan konsisten dengan aturan main yang telah disepakati bersama, dan menumbuhkan kesadaran dan rasa memiliki terhadap apa yang telah disepakati.

Dunia bisnis adalah sebuah manifestasi dari interaksi sosial yang merupakan bagian dari kehidupan sosial itu sendiri. Menjalankan bisnis dengan arif dan bijak dalam setiap strategi dan pengembangannya adalah merupakan sebuah kebanggaan secara psikologis karena di situ terkait berbagai macam sendi yaitu relationship, simbiosis mutualisme serta 
penghargaan atas orang lain yang sangat pantas untuk dilakukan dengan penuh kesantunan baik secara etika maupun moral.

\section{SIMPULAN DAN SARAN}

\section{Simpulan}

Berdasarkan hasil pembahasan, maka dapat disimpulkan bahwa:

1. Gaya belajar pengusaha kecil bidang agribisnis di Kota Kendari tersebar ke dalam 4 (empat tipe gaya belajar), dengan urutan sebagai berikut: 38,89\% bertipe assimilator, $27,78 \%$ bertipe konverger, $16,67 \%$ masing-masing untuk tipe akomodator dan diverger.

2. Perilaku bisnis pengusaha kecil bidang agribisnis di Kota Kendari mengelompok pada perilaku III (100\%), yaitu perilaku bisnis yang beretika (clean businness). Diantara 100\% pengusaha yang berperilaku clean business, terdapat $38,89 \%$ pengusaha yang perilaku clean business sangat kuat (tinggi) dan $61,11 \%$ pengusaha yang perilaku clean businessnya agak rendah.

\section{Saran}

Berdasarkan kesimpulan di atas maka dapat disarankan agar:

1. Para pengusaha kecil bidang agribisnis di Kota Kendari dapat mengoptimalkan berbagai keunggulan gaya belajar dan perilaku bisnis yang telah dimilikinya, serta mengurangi kelemahan-kelemahan yang ada dan banyak menjalin kerjasama dengan pengusaha-pengusaha lain yang dianggap dapat menutupi berbagai kelemahan yang dimiliki.

2. Para akademisi dapat menyampaikan kepada mahasiswa sebagai calon wirausaha agar lebih mengenal gaya belajarnya sendiri kemudian mencari partner dengan tipe gaya belajar yang lain agar dapat menutupi kelemahan bisnis yang dimilikinya.

3. Pemerintah dan lembaga-lembaga keuangan dapat memberi kepercayaan yang lebih besar dalam pemberian kredit usaha karena telah teridentifikasi perilaku clean bisnis dari para pengusaha kecil bidang agribisnis di Kota Kendari. 


\section{DAFTAR PUSTAKA}

Jafam-ICT.com. 2009. Usaha Perdagangan di Kendari. http://beritadaerah.com /news.php?pg=berita_sulawesi\&id=9898\&sub=column\&page $=35$.

Mitimahasiswa. 2009. Gaya Belajar (Terobosan Peningkatan Kualitas Sumber Daya Manusia). http:// www.mitimahasiswa.com/2009/07/gaya-belajarterobosan-peningkatan.html" rel="canonical" $>$.

Nurjaman, U. 2009. Gaya Belajar.http://zalvakapeta.blogspot.com/2009/02/gaya-belajar.html" rel="canonical">.

Setyowati, E. 2009. Tantangan Permasalahan Struktur dan Perilaku Agribisnis Saat Ini. http://enistain76.blogspot.com/2009/05/tantangan-danpermasalahan-struktur-dan.html.

Welirang, F. 2007. Revitalisasi Republik, Perspektif Pangan dan Kebudayaan. Grafindo. Jakarta. 